\title{
Effective Personality as a Protective Factor in Teachers' Occupational Health
}

\author{
Cristina Di-Giusto ${ }^{1}\left(\mathbb{D}\right.$, María Eugenia Martín-Palacio ${ }^{2, *(\mathbb{D})}$, Marta Soledad García-Rodríguez ${ }^{3}(\mathbb{D}$, \\ Francisco Javier Sánchez-Sánchez ${ }^{4}$, Raquel de la Fuente-Anuncibay ${ }^{1}$ D , Andrés Fernando Avilés-Dávila ${ }^{2}$ D \\ and Cesáreo Gabriel García-Rodríguez ${ }^{5}$
}

check for updates

Citation: Di-Giusto, C.; Martín-Palacio, M.E. García-Rodríguez, M.S.; Sánchez-Sánchez, F.J.; de la Fuente-Anuncibay, R.; Avilés-Dávila, A.F.; García-Rodríguez, C.G. Effective Personality as a Protective Factor in Teachers' Occupational Health. Int. J. Environ. Res. Public Health 2022, 19, 2907. https://doi.org/10.3390/ ijerph19052907

Academic Editors: Esteban Agulló-Tomás, Joan Boada-Grau and Jose Antonio Llosa Fernández

Received: 10 January 2022

Accepted: 28 February 2022

Published: 2 March 2022

Publisher's Note: MDPI stays neutral with regard to jurisdictional claims in published maps and institutional affiliations.

Copyright: (c) 2022 by the authors Licensee MDPI, Basel, Switzerland. This article is an open access article distributed under the terms and conditions of the Creative Commons Attribution (CC BY) license (https:// creativecommons.org/licenses/by/ $4.0 /)$
1 Department of Educational Sciences, University of Burgos, 09001 Burgos, Spain; cdi@ubu.es (C.D.-G.); raquelfa@ubu.es (R.d.l.F.-A.)

2 Department of Research and Psychology in Education, University Complutense of Madrid, 28040 Madrid, Spain; andresav@ucm.es

3 Departament of Education Sciences, University of Oviedo, 33005 Oviedo, Spain; martagar@uniovi.es

4 Department of Education and Culture of the Principality of Asturias, 33007 Oviedo, Spain; franciscojavier.sanchezsanchez@asturias.org

5 Department of Web Application Development, ESIC (Busicess School), Pozuelo de Alarcón, 28223 Madrid, Spain; cgarcia_1963@hotmail.com

* Correspondence: mariaeugeniamartin@edu.ucm.es

\begin{abstract}
In recent decades, there has been a growing body of research showing the relationship between teaching work and several health problems, both physical and psychological. Some of these studies relate personal competencies and resources to teachers' occupational health. Based on the construct of Effective Personality, proposed by Martin del Buey, Martín Palacio, and Di Giusto, the aim was to analyse the relationship between the dimensions of the construct and Teachers' Occupational Health. A descriptive cross-sectional design was used. It was based on the application of the Teacher Health Questionnaire (CSD) and the Efficacy Personality Questionnaire-Adults (CPEA). The sample consisted of 700 non-university teachers aged between 26 and 66 years, $M=47.65$ $S D=8.68$. Descriptive, correlational, linear regression, and structural equation analyses were carried out. The results confirmed the relationship between the Efficacy Personality construct and Teachers Occupational Health $\left(r=0.45^{* *}\right)$. In addition, the regression analysis indicated the relevance of each factor of Efficacy Personality in the factors of Teachers' Occupational Health. The variance of Self-efficacy is the most explained by the dimensions of Efficacy Personality (40.2\%), with positive relationships. The structural equation analysis confirmed the influence between Efficacy Personality and the factors of Self-Efficacy and Satisfaction, explaining $55.0 \%$ of the variance. It is concluded, therefore, that Efficacy Personality has a protective function on Teacher Occupational Health; the higher the Efficacy Personality scores are, the better the results in health gain-Self-efficacy and satisfaction-and the lower the result in health loss-burnout, cognitive affections, musculoskeletal affections, and voice alterations. These results facilitate the design of prevention and intervention programmes for teachers' occupational health, which strengthen and improve personal and socioaffective competencies.
\end{abstract}

Keywords: effective personality; occupational health; satisfaction; teacher

\section{Introduction}

The Healthy Work Environment model proposed by the World Health Organisation [1], proposes four levels of intervention to protect health, safety, and well-being in the workplace: the physical work environment, the psychosocial environment, personal health resources, and the participation of the workplace/company/organisation in the community. However, despite the time that has elapsed, most of the actions have been developed with strategies that focus mainly on the physical work environment and workplace participation 
in the community, but hardly any action is taken on the psychosocial work environment and personal health resources.

In the field of the teaching profession, studies have focused mainly on variables such as emotional intelligence [2-9].

Psychology and the social sciences have highlighted the importance of studying these variables, pointing out the importance of also analysing the role that other personal resources and variables can play in well-being and health at work. In the field of the teaching profession, greater emphasis has traditionally been placed on organisational variables; however, there is currently a demand for greater integration of work and personal variables to explain psychosocial risk factors at work and their consequences. In this sense, some authors [10] argue that most research has focused mainly on analysing aspects of the work environment, neglecting other aspects such as the internal functioning of the stress process and, to a lesser extent, personality variables.

In this sense, some authors point out the importance of developing personal competencies and resources to achieve healthy work organisations [11-15].

Attention to personal resources is a necessity within the framework of the current Healthy Work Environment model, which defines the work environment as being in which workers and employers collaborate, with the use of a continuous improvement process being important to protect the health, safety, and well-being of all employees and the sustainability of the workplace [1]. Moreover, this interest is supported by the current national and European Union (EU) social policy and the current legal system, namely the Law 31/1995 of 8 November 1995 on the Prevention of Occupational Risks [16], as well as its provisions, calling for the strengthening of personal resources as the main objective to achieve an improvement in health and well-being at work. Together, with the improvement of organisational and work-related teaching variables, it is necessary to focus on the development of personal competencies and resources that can play a moderating and controlling role in health risk factors.

Our work aimed to contribute to this demand in the teaching field. To this end, we analysed the relationship between various personal resources (Self-esteem, Self-concept, Motivation, Attribution, Expectations, Coping with Problems, Decision-making, Communication, Empathy, and Assertiveness) integrated in the Efficient Personality construct proposed by Martin Del Buey, Martinpalacio, and Di Giusto, and Occupational Health, the construct for which the model of Fernández-Puig, Longas, Chamarro, and Virgili [17] is assumed, both in its manifestations of health loss (Exhaustion, Cognitive Affections, Voice Alterations, and Musculoskeletal Affections) and in its manifestations of health gain and well-being (Self-Efficacy and Satisfaction).

The Exhaustion dimension considers the feeling of physical and emotional exhaustion caused by the teaching activity. The importance of this factor is consistent with its involvement in health. According to its authors, it is the factor with the greatest weight in the variance explained. Firstly, this factor corresponds to the burnout dimension of burnout, which is considered to be the central dimension of this syndrome [18-20]. It has been pointed out that burnout leads to a deterioration in the functioning of most physiological and psychological systems, thus posing an increased risk of developing respiratory disorders, gastrointestinal disorders, and viral diseases [21-26]. It has also been shown to play a mediating role between the experience of stress and the development of depressive disorders [20,27]. Some authors point out that burnout is the decisive element in the negative spirals, or loss of health, as defined in the Job Demands and Resources Model (JDR), indicating that the demands placed on the professional are excessive and that more organisational, material and training resources are required to reduce the teacher's load [28-30]. In this sense, burnout is a consequence of experiencing a situation of overload and is therefore considered an indicator of harmful working conditions [20,31,32]. 
The Satisfaction dimension refers to satisfaction with the teaching profession, the enjoyment and energy to carry it out, and the feeling of happiness in being a teacher. It is a factor that captures the affective well-being related to work. It is a factor close to engagement, with dimensions of vigour, enjoyment, and absorption, and also to flow, as it assesses a positive affective and motivational relationship with work. In studies on burnout, satisfaction is a factor that correlates negatively with burnout and depersonalisation [18]; it has also been shown to decrease the chances of generating stress [33] and to increase empathy towards and satisfaction of the recipients [34]. Satisfaction in teaching is related to emotions of joy, pride, and enjoyment, i.e., the presence of positive emotions. It is, therefore, a factor that indicates well-being and an optimal state for the development of new competencies and nurturing interpersonal relationships $[35,36]$.

The Voice Alterations dimension considers the presence of physical sensations of discomfort related to the voice, specifically: aphonia, or loss of voice, vocal fatigue, and discomfort in the neck, these aspects being frequent in the teaching profession [37-39].

The dimension Musculoskeletal Affections refer to muscular discomfort mainly with the spine and back. This musculature is the most affected, with the most frequent damage being: contractures, cervical or back pain, herniated discs, and lumbago [40-42]. It is related to associated with sustained stressful situations based on stress and somatisation processes [37,43].

The Cognitive Affections dimension assesses the presence of dysfunctions in the cognitive abilities of concentration, memory, distractions, and obsessive thinking. This symptomatology is a consequence of the high concentration of glucocorticoids in the hippocampus caused by the experience of emotional exhaustion and distress [44,45]. On the other hand, it is one of the negative effects that participate in the generation of negative spirals of health loss. The professional perceives that their cognitive capacities, essential for the regulation and management of teaching, have diminished, i.e., their professional competence, and this, in turn, produces an increase in the feeling of vulnerability and insecurity, which again increases the experience of distress and the consequent affectation of cognitive capacities. This spiralling process can lead to a crisis of professional efficacy or to the development of Job Burnout Syndrome (WBS) [21,29,46].

The Self-efficacy dimension assesses the teacher's perception of his or her ability to achieve positive and meaningful results, as well as his or her assessment of his or her professional competence and capabilities. It indicates a positive affective state in relation to teaching, which facilitates the generation of gain spirals [47]. It is considered a central element in identifying gain or loss spiral processes. Numerous studies indicate its relationship with the physical and psychological well-being of teachers and with a good quality of interpersonal relationships. Furthermore, various studies consider it to be an important preventive element in professional health [48-50]. A broad conception of the term self-efficacy, as confidence in one's own competencies, is chosen, since the more restrictive conception of the term self-efficacy requires reference to overcoming obstacles [51].

Several models attempt to determine which variables decrease the likelihood that individuals will experience symptoms that deteriorate their occupational health. These include Kobasa's model [52,53], which indicates that individuals with high scores on resilient personality dimensions have better characteristics in the face of stress at work or in everyday life, and the Coherence Construct developed by Antonovsky [54], which focuses on exploring the origin of health rather than explaining the causes of illness.

In this study, the construct of Effective Personality [55] was used, as it is a model that integrates personal and socio-affective competencies, establishes a related structure between them, and factors them into four broad dimensions that are interrelated to each other. In the construct, these variables are grouped around four categories or dimensions: Self-esteem, Labor Self-Realisation, Resolute Self-efficacy, and Social Self-Realisation. 
The Self-esteem dimension measures indicators of self-concept and self-worth and integrates valuational aspects of the person such as good knowledge and appreciation of oneself, a high valuation and confidence in one's cognitive-emotional and social resources, and accurate recognition of one's limitations. The Labor Self-Realisation dimension highlights the relationship between personal knowledge and the attribution of success to a defined and positive capacity and effort, intrinsic motivation, and achievement in the activities of daily life. The Resolving Self-efficacy dimension refers to the ability to cope with problems and challenges. It refers to decision-making and coping with problems. Finally, the Social Self-Realisation dimension involves communication skills, assertiveness, and empathy. This dimension highlights the link between self-perceived ability or competence to establish and maintain relationships with others and expectations of success in future social relationships.

Although the variables of the Efficacy Personality model have been the object of specific research relating them to aspects linked to health $[14,49,56,57]$, in this study, these variables are considered to form a unitary construct.

To these advantages of the model must be added its application in research that has allowed the construction of assessment instruments in different contexts, the establishment of multivariate modal typologies in different ages, as well as the development of intervention programmes developed to work jointly with each of the dimensions assessed.

We aimed to analyse the causal relationship between the dimensions of the Efficacy Personality construct and the dimensions that make up the model of Teachers' Occupational Health. The aim was to verify that the dimensions of the effective personality construct are mainly related to the dimensions of gain and loss of health in the teaching work environment.

Specifically, each of the dimensions of Efficacy Personality (Self-esteem, Labor SelfRealisation, Resolute Self-Efficacy and Social Self-Realisation) were analysed with each of the dimensions of Teachers' Occupational Health (Exhaustion, Satisfaction, Voice Disturbance, Musculoskeletal Disorders, Cognitive affectations, and Self-efficacy).

It was hypothesised that there is a positive influence between the Efficacy Personality and the manifestations of health gain (Self-efficacy and Satisfaction) and a negative influence with those of loss (Exhaustion, Cognitive Affections, Musculoskeletal Disorders, and Voice Disturbance).

\section{Method}

This research was based on a descriptive, correlational, and inferential cross-sectional design [58]. In order to obtain information about the dimensions present in the constructs of Effective Personality and Teacher Occupational Health, online questionnaires were applied.

With the data obtained, analyses were carried out to verify the relationship of dependence of the dimensions present in both constructs through correlations, regressions, and structural equations.

Informed consent was obtained from the study participants, and the principles of confidentiality, voluntariness, data protection, and ethical standards for this type of study were observed.

\subsection{Participants}

The inclusion criterion for participants was to belong to the population of nonuniversity teachers in the 435 public schools of the Principality of Asturias, made up of 11,796 people $(72.5 \%$ female and $27.5 \%$ male). In this research, an informatic application has been used to ensure that only the target population, teachers from public schools in the Principality of Asturias, who can only fill in the form once, could participate in the study. Another criterion for inclusion was the voluntary nature of participation. 
The final sample consisted of 700 teachers, but one teacher was excluded for completing only one of the questionnaires. The 699 participants constituted a representative sample of the study population at a confidence level of $95 \%$ and with a margin of error of $5 \%$. Their distribution according to the different socio-demographic variables is shown in Table 1. As can be seen in Table 1, the distribution of the sample is consistent with the population in terms of the variables gender, affiliation, educational stage, and location of the school, which can be considered a guarantee of the representativeness of the sample.

Table 1. Descriptive statistics for the population and the sample.

\begin{tabular}{|c|c|c|}
\hline Variable & Population & Sample \\
\hline $\mathrm{N}$ & 11.796 & 699 \\
\hline Age & & $M=47.65 ; S D=8.68$ \\
\hline \multicolumn{3}{|l|}{ Sex } \\
\hline Female & $8.562(72.5 \%)$ & $506(72.6 \%)$ \\
\hline Male & $3.234(27.5 \%)$ & $193(27.6 \%)$ \\
\hline \multicolumn{3}{|l|}{ Affiliation } \\
\hline Career or permanent civil servants & $4198(64.4 \%)$ & $497(71.1 \%)$ \\
\hline Interim or permanent civil servants & $7598(35.6 \%)$ & $202(28.9 \%)$ \\
\hline \multicolumn{3}{|l|}{ Educational stage } \\
\hline Teachers & $5615(47.6 \%)$ & $275(39.3 \%)$ \\
\hline Secondary & $4976(42.2 \%)$ & $297(42.5 \%)$ \\
\hline Vocational Education & $730(6.2 \%)$ & $89(12.7 \%)$ \\
\hline Other education & $475(4.0 \%)$ & $38(5.5 \%)$ \\
\hline \multicolumn{3}{|l|}{ Location of the centre } \\
\hline $\begin{array}{l}\text { Large population centres (more than } \\
100,000 \text { inhabitants) }\end{array}$ & $\begin{array}{l}129 \text { centres } \\
(29.65 \%)\end{array}$ & $289(41.5 \%)$ \\
\hline $\begin{array}{l}\text { Small population centres (between } 10,000 \text { and } \\
100,000 \text { inhabitants) }\end{array}$ & $\begin{array}{l}194 \text { centres } \\
(44.60 \%)\end{array}$ & $277(39.5 \%)$ \\
\hline $\begin{array}{l}\text { Rural area (in population centres with less than } \\
10,000 \text { inhabitants) }\end{array}$ & $\begin{array}{l}112 \text { centres } \\
(25.75 \%)\end{array}$ & $133(19.0 \%)$ \\
\hline
\end{tabular}

\subsection{Instruments}

Two questionnaires were used for this study:

- $\quad$ Teaching Health Questionnaire (CSD) by Fernández-Puig, Longas, Chamarro and Virgili [17]. It consists of 23 items integrated into six dimensions or factors:

Exhaustion: it has 3 items and a Cronbach's Alpha reliability of 0.87 . It considers the feeling of physical and emotional exhaustion caused by carrying out the teaching activity (for example: item 12. I feel physically exhausted at the end of my workday).

Satisfaction: consists of 5 items with a Cronbach's Alpha reliability of 0.79 . It includes the effective well-being related to work (for example: item 10. I have a good time at work.).

Voice disturbance: has 3 items and a Cronbach's Alpha reliability of 0.82 . It considers the presence of physical sensations of discomfort related to the voice, specifically: aphonia, or loss of voice; vocal fatigue, and discomfort in the neck (for example: item 8. I feel hoarse or dysphonic).

Musculoskeletal disorders: has 3 items and a Cronbach's Alpha reliability of 0.73. They refer to muscular discomfort mainly with the spine and back (for example: item 2. My back hurts from the activity I do.). 
Cognitive affectations: it has 4 items and a Cronbach's Alpha reliability of 0.71 . It assesses the presence of dysfunctions in the cognitive abilities of concentration, memory, distractions, and obsessive thinking (for example: item 11. There are times when I have more distractions than usual.).

Self-efficacy: consists of 5 items and a Cronbach's Alpha reliability of 0.71 . It is related to the teacher's perception of his or her ability to obtain positive and significant results, as well as his or her assessment of his or her professional competence and capabilities. (for example: item 22. When I finish a job, I am often happy with the results.).

The response format of this questionnaire is a Likert-type scale with five response options: 1 = Strongly Disagree; 2 = Disagree; 3 = Neither Agree nor Disagree; 4 = Agree; $5=$ Strongly Agree. It can be applied individually or collectively and lasts about $10 \mathrm{~min}$. It can be considered as an evaluation tool that includes the most relevant aspects in the evaluation of teachers' health and that is framed in the current health surveillance policies.

- Questionnaire of Effective Personality-Adults (CPE-A) by Castellanos, Martín-Palacio, and Dapelo [59]. The CPE-A consists of 30 items integrated into four dimensions that define the Efficacy Personality model:

Self-esteem: consists of 8 items and has a Cronbach's Alpha reliability of 0.71 . It assesses knowledge and appreciation of one's physique, confidence in one's cognitiveemotional and social resources, and a recognition of one's limitations. (for example: item 3. I feel very good about my physical appearance.).

Laboral Self-Realisation: has 8 items and a Cronbach's Alpha reliability of 0.78 . It analyses personal knowledge and attribution of success to a defined and positive ability and effort, intrinsic motivation, and achievement expectancy. (for example: item 5. I am successful in a task because I work hard to do a good job.).

Resolute Self-Efficacy: presents 5 items with a Cronbach's Alpha reliability of 0.59 . It analyses effective coping with challenges and appropriate decision making. (for example: item 12. To make a decision I gather all the information I can find).

Social Self-Realisation: has 9 items and a Cronbach's Alpha reliability of 0.83 . It assesses the person's communication, assertiveness, and empathy, as well as their relationships with their environment. (for example: item 6. I make friends easily).

The response format of this questionnaire is a Likert-type scale with five response options corresponding to: 1 = Never; 2 = Few times; 3 = Sometimes; $4=$ Many times; $5=$ Always. It can be applied individually or collectively and lasts about $15 \mathrm{~min}$. In short, it is an instrument that allows an approximation to the characterisation of the dimensions that make up the Effective Personality construct and makes it possible to identify strengths and personal/group requirements that can guide the intervention in programmes following the needs detected.

\subsection{Procedure}

To carry out this study, a form was created using the Microsoft Forms application in Office 365. This application makes it possible to create questionnaires, surveys, and personalised records and share them with the users of an organisation and export the results to Excel in a completely anonymous and confidential way. In addition, the use of the application ensures that only the subjects to whom the study was addressed, teachers from public schools in the Principality of Asturias, could participate in the study, who could only complete the form once.

This form contained the items of the two reference instruments used in the study: the Efficacy Personality Questionnaire-Adults (CPE-A) and the Teacher Health Questionnaire (CSD). 
Through the area of Occupational Health, within the Administrative Management and Labour Relations Service of the Regional Ministry of Education and Culture, the anonymous and voluntary collaboration of the teaching staff was requested through the Educastur e-mail, emphasising the scientific purpose of the study and the confidential and anonymous nature of the responses.

The response time was estimated at less than $30 \mathrm{~min}$ and data collection was carried out over a period of two school months.

This study complies with the ethical criteria established in the Code of Conduct of the Ethics and Deontology Committee of the Complutense University, approved by the Governing Council on 11 June 2008, and the research procedure followed does not contradict any of these criteria.

\subsection{Analysis of Data}

The SPSS 25.0 and AMOS 24.0 programs were used for the statistical treatment of the data. The independent variable analysed was Efficacy Personality, and the dependent variable was Occupational Health. In order to meet the research objective, a descriptive analysis of both questionnaires was carried out to find out the levels of Efficacy Personality and Occupational Health. To determine the relationship between both models, bivariate Pearson correlations were performed between global and specific scores, as well as multiple linear regressions (by successive steps) to determine the percentage explained by the factors of Efficient Personality in each of the factors of Occupational Health, taking into account the Bonferroni correction and structural equation analysis to determine the influence of Efficacy Personality on the Occupational Health model. The structural equation modelling (SEM) analysis was carried out using the Maximum Likelihood procedure (previously checking multivariate normality). In addition, a bootstrap of 10,000 samples was used. The fit indicators used were the following

- $\quad$ CMIN/DF indicates the absolute fit of the model and values below 3 are considered acceptable [60].

- $\quad$ GFI Goodness of Fit Index ranges from 0 to 1 and considers models above 0.90 as adequate [61].

- $\quad$ CFI Comparative Fit Index is one of the most widely used and best performing relative fit indices [62], it also ranges from 0 to 1 , with a value of 0.90 being the minimum required to defend the model [63].

- $\quad$ NFI Normed Fit Index assesses the decrease in the $\chi^{2}$ statistic of the adopted model with respect to the base model. It must reach a minimum value of 0.90

- $\quad$ SRMR Standardised Root Mean-Square is a measure of the amount of model error, indicating a good fit with values below 0.05 [64].

\section{Results}

Table 2 shows the descriptive analyses of the participant's scores on the two instruments. It can be seen that the mean scores obtained in Occupational Health and Efficacy Personality are above the theoretical mean in all cases, except for Voice Alterations, where they are below. Furthermore, it is observed that both skewness and kurtosis are between \pm 2 values, which indicates normality of the variables according to authors such as Pérez [65]. 
Table 2. Descriptive of Occupational Health and Efficacy Personality.

\begin{tabular}{|c|c|c|c|c|c|c|c|c|}
\hline & N Items & $\begin{array}{c}\text { Theoretical } \\
\text { Mean }\end{array}$ & $\begin{array}{c}\text { Empirical } \\
\text { Mean }\end{array}$ & $S D$ & Minimun & Maximum & Skewness & Kurtosis \\
\hline CDS satisfaction & 5 & 15 & 19.63 & 3.84 & 5 & 25 & -0.73 & 0.39 \\
\hline CDS self-efficacy & 5 & 15 & 20.28 & 2.78 & 9 & 25 & -0.74 & 1.19 \\
\hline CDS exhaustion & 3 & 9 & 9.86 & 3.07 & 3 & 15 & -0.24 & -0.62 \\
\hline CDS voice alterations & 3 & 9 & 7.95 & 2.95 & 3 & 15 & 0.11 & -0.77 \\
\hline $\begin{array}{l}\text { CDS musculoskeletal } \\
\text { affections }\end{array}$ & 3 & 9 & 9.51 & 3.28 & 3 & 15 & -0.22 & -0.82 \\
\hline CDS cognitive affections & 4 & 12 & 13.32 & 3.28 & 4 & 20 & -0.40 & -0.14 \\
\hline CDS total & 23 & 69 & 77.27 & 12.31 & 38 & 115 & 0.02 & 0.23 \\
\hline CPE-A: Self-esteem & 8 & 24 & 29.77 & 4.01 & 16 & 40 & -0.28 & 0.58 \\
\hline $\begin{array}{l}\text { CPE-A: Labour } \\
\text { Self-Realisation }\end{array}$ & 8 & 24 & 33.15 & 3.64 & 21 & 40 & -0.17 & 0.02 \\
\hline $\begin{array}{l}\text { CPE-A: Resolute } \\
\text { Self-Efficacy }\end{array}$ & 5 & 15 & 19.73 & 2.70 & 8 & 25 & -0.40 & 0.51 \\
\hline $\begin{array}{l}\text { CPE-A: Social } \\
\text { Self-Realisation }\end{array}$ & 9 & 27 & 34.55 & 5.11 & 17 & 45 & -0.55 & 0.33 \\
\hline $\begin{array}{l}\text { CPE-A: Total Effective } \\
\text { Personality }\end{array}$ & 30 & 90 & 117.20 & 12.15 & 766 & 150 & -0.19 & 0.35 \\
\hline
\end{tabular}

In order to determine the relationship between the constructs of Effective Personality and Teacher Occupational Health a Pearson correlation analysis was carried out when it was found that the variables were normally distributed, as indicated by the skewness and kurtosis. The results of which are shown in Table 3, where it can be seen that the correlations found between the total scores of the Effective Personality construct and the Teacher Occupational Health construct are positive and significant $(p<0.001)$.

Table 3. Correlations between Effective Personality and Teacher Health.

\begin{tabular}{|c|c|c|c|c|c|}
\hline & $\begin{array}{c}\text { CPE-A: Total } \\
\text { Effective } \\
\text { Personality }\end{array}$ & $\begin{array}{c}\text { CPE-A: } \\
\text { Self-Esteem }\end{array}$ & $\begin{array}{l}\text { CPE-A: Labour } \\
\text { Self-Realisation }\end{array}$ & $\begin{array}{l}\text { CPE-A: Resolute } \\
\text { Self-Efficacy }\end{array}$ & $\begin{array}{c}\text { CPE-A: Social } \\
\text { Self-Realisation }\end{array}$ \\
\hline CDS Total & $0.45^{* *}$ & $0.41^{* *}$ & $0.32^{* *}$ & 0.36 ** & $0.32 * *$ \\
\hline CDS Satisfaction & $0.47^{* *}$ & $0.33^{* *}$ & $0.43^{* *}$ & $0.35^{* *}$ & $0.37 * *$ \\
\hline CDS Self-efficacy & $0.59 * *$ & $0.50^{* *}$ & $0.60^{* *}$ & $0.39 * *$ & $0.39 * *$ \\
\hline CDS Exhaustion & $-0.20 * *$ & $-0.24^{* *}$ & $-0.08 *$ & $-0.19 * *$ & $-0.14^{* *}$ \\
\hline CDS Voice Alterations & $-0.08 *$ & $-0.11^{* *}$ & -0.01 & $-0.09 *$ & -0.05 \\
\hline $\begin{array}{c}\text { CDS Musculoskeletal } \\
\text { Affections }\end{array}$ & -0.06 & $-0.11^{* *}$ & 0.03 & -0.07 & -0.04 \\
\hline CDS Cognitive Affections & $-0.30 * *$ & $-0.28^{* *}$ & $-0.15^{* *}$ & $-0.28 * *$ & $-0.23^{* *}$ \\
\hline
\end{tabular}

When analysing the relationships between the variables that make up both constructs, positive relationships were found, being equally as significant $(p<0.001)$ between the Satisfaction and Self-efficacy dimensions with all the dimensions of the Efficacy Personality. In contrast, negative relationships were found between the dimensions of Burnout and Cognitive Disturbances with all the factors of Effective Personality (moderately). Additionally, to a lesser extent, between the dimensions Musculoskeletal Affections and Voice Alterations with Self-esteem, and Voice Alterations is also negatively related to Resolute Self-efficacy.

Secondly, the results obtained in the multiple linear regression analyses to determine which dimensions of Efficacy Personality influence the dimensions of Occupational Health are presented. 
First, regression was performed on the satisfaction factor. It was found that, on the whole, the assumptions for the application of multiple linear regression are met, with the exception of normality, so the results were be taken with caution. There were significant correlations between all variables $p<0.05$ indicating an adequate linear association. The Durbin-Watson value $=1.80$, a value between 1.5 and 2.5 , so independence is met. The eigenvalues of the variance inflation factor (VIF) are between 0.01 and 3.97, all less than 10, which ensures non-multicollinearity. The standardised residuals conform to a homoscedastic distribution. The Kolmogorv-Smirnov $(K-S)$ test showed that the normality assumption is not met $(p<0.05)$. The regression showed that in the Satisfaction dimension, the dimensions of Labor Self-Realisation, Social Self-Realisation, and Resolute Efficacy were significant predictors, explaining $24.3 \%$ of the variance, in all cases with a positive relationship (Table 4).

Table 4. Regression Analysis of the Influence of Effective Personality Factors on Satisfaction.

\begin{tabular}{|c|c|c|c|c|c|c|c|c|c|}
\hline \multirow{2}{*}{ DV } & \multirow{2}{*}{ IV } & \multirow{2}{*}{ B } & \multirow{2}{*}{$\beta$} & \multicolumn{2}{|c|}{ 95\% Confidence Interval } & \multirow{2}{*}{$R$} & \multirow{2}{*}{$R^{2}$} & \multirow{2}{*}{$\begin{array}{c}R^{2} \\
\text { Corrected }\end{array}$} & \multirow{2}{*}{$\begin{array}{c}\text { Change } \\
\text { at } R^{2}\end{array}$} \\
\hline & & & & Lower Limit & Upper Limit & & & & \\
\hline \multirow[t]{4}{*}{ Satisfaction } & (Constant) & 0.76 & & -1.75 & 3.26 & \multirow{4}{*}{0.49} & \multirow{4}{*}{0.24} & \multirow{4}{*}{0.24} & \multirow{4}{*}{$0.01 *$} \\
\hline & Labor Self-Realisation & 0.29 & 0.27 * & 0.21 & 0.37 & & & & \\
\hline & Social Self-Realisation & 0.16 & 0.21 * & 0.10 & 0.21 & & & & \\
\hline & Resolute Self-Efficacy & 0.19 & 0.14 * & 0.09 & 0.30 & & & & \\
\hline
\end{tabular}

* Bonferroni correction ( $p$-value $0.05 / 3$ tests $=0.016)$.

Secondly, the regression was carried out on the Self-efficacy factor. After verifying that, on the whole, the assumptions for the application of multiple linear regression were met, except for normality, the results were taken with caution. There are significant correlations between all variables $p<0.05$, indicating an adequate linear association. The DurbinWatson value $=1.92$, a value between 1.5 and 2.5 , so independence is met. The eigenvalues of VIF are between 0.01 and 3.97, all less than 10, which ensures non-multicollinearity. The standardised residuals conform to a homoscedastic distribution. The K-S test shows that the normality assumption is not met $(p<0.05)$. The regression showed that in Selfefficacy, the dimensions of Labor Self-Realisation, Self-esteem, and Social Self-Realisation were significant predictors explaining $40.2 \%$ of the variance, in all cases with a positive relationship (Table 5).

Table 5. Regression Analysis of the Influence of Effective Personality Factors on Self-Efficacy.

\begin{tabular}{|c|c|c|c|c|c|c|c|c|c|}
\hline \multirow{2}{*}{ DV } & \multirow{2}{*}{ IV } & \multirow{2}{*}{ B } & \multirow{2}{*}{$\beta$} & \multicolumn{2}{|c|}{ 95\% Confidence Interval } & \multirow{2}{*}{$R$} & \multirow{2}{*}{$R^{2}$} & \multirow{2}{*}{$\begin{array}{c}R^{2} \\
\text { Corrected }\end{array}$} & \multirow{2}{*}{$\begin{array}{c}\text { Change } \\
\text { at } R^{2}\end{array}$} \\
\hline & & & & Lower Limit & Upper Limit & & & & \\
\hline \multirow[t]{4}{*}{$\begin{array}{c}\text { Self- } \\
\text { Efficacy }\end{array}$} & (Constant) & 3.16 & & 1.59 & 4.74 & \multirow{4}{*}{0.63} & \multirow{4}{*}{0.40} & \multirow{4}{*}{0.40} & \multirow{4}{*}{$0.01 *$} \\
\hline & $\begin{array}{c}\text { Labor } \\
\text { Self-Realisation }\end{array}$ & 0.35 & $0.46^{*}$ & 0.29 & 0.41 & & & & \\
\hline & Self-esteem & 0.11 & $0.16^{*}$ & 0.05 & 0.16 & & & & \\
\hline & $\begin{array}{c}\text { Social } \\
\text { Self-Realisation }\end{array}$ & 0.07 & $0.13 *$ & 0.03 & 0.10 & & & & \\
\hline
\end{tabular}

${ }^{*}$ Bonferroni correction $(p$-value $0.05 / 3$ tests $=0.016)$.

Thirdly, regression was performed on the Exhaustion factor. After verifying that, on the whole, the assumptions for the application of multiple linear regression were met, except for normality, the results were taken with caution. There are significant correlations between all variables $p<0.05$ indicating an adequate linear association. The Durbin-Watson value $=1.96$, a value between 1.5 and 2.5, so independence is met. The eigenvalues of VIF are between 0.01 and 3.98, all less than 10, which ensures non-multicollinearity. The standardised residuals conform to a homoscedastic distribution. The $K-S$ test shows that the normality assumption is not met $(p<0.05)$. The regression showed that with respect 
to Exhaustion, the dimensions of Self-esteem, Labor Self-Realisation, and Resolute SelfEfficacy were significant predictors explaining $7.5 \%$ of the variance, in a negative sense in all of them except for Labor Self-Realisation (Table 6).

Table 6. Regression Analysis of the Influence of Effective Personality Factors on Exhaustion.

\begin{tabular}{|c|c|c|c|c|c|c|c|c|c|}
\hline \multirow{2}{*}{ DV } & \multirow{2}{*}{ IV } & \multirow{2}{*}{ B } & \multirow{2}{*}{$\beta$} & \multicolumn{2}{|c|}{ 95\% Confidence Interval } & \multirow{2}{*}{$R$} & \multirow{2}{*}{$R^{2}$} & \multirow{2}{*}{$\begin{array}{c}R^{2} \\
\text { Corrected }\end{array}$} & \multirow{2}{*}{$\begin{array}{c}\text { Change } \\
\text { at } R^{2}\end{array}$} \\
\hline & & & & Lower Limit & Upper Limit & & & & \\
\hline \multirow[t]{4}{*}{ Exhaustion } & (Constant) & 14.38 & & 12.24 & 16.52 & \multirow{4}{*}{0.27} & \multirow{4}{*}{0.07} & \multirow{4}{*}{0.07} & \multirow{4}{*}{$0.01 *$} \\
\hline & Self-esteem & -0.20 & $-0.26^{*}$ & -0.28 & -0.13 & & & & \\
\hline & $\begin{array}{c}\text { Labor } \\
\text { Self-Realisation }\end{array}$ & 0.13 & $0.15 *$ & 0.05 & 0.21 & & & & \\
\hline & $\begin{array}{c}\text { Resolute } \\
\text { Self-Efficacy }\end{array}$ & -0.13 & $-0.12 *$ & -0.24 & -0.03 & & & & \\
\hline
\end{tabular}

* Bonferroni correction ( $p$-value $0.05 / 3$ tests $=0.016)$.

Fourthly, the regression was carried out on the factor Voice Alterations. After verifying that there were no significant correlations between this factor and Labor Self-Realisation and Social Self-Realisation, these were excluded from the analysis. The rest of the factors, as a whole, meet the assumptions for the application of linear regression, with the exception of normality, so the results will be taken with caution. There are significant correlations between all variables at $p<0.05$ indicating an adequate linear association. The DurbinWatson value $=1.91$, a value between 1.5 and 2.5 , so independence is met. The eigenvalues of VIF are between 0.01 and 1.99, all less than 10, which ensures non-multicollinearity. The standardised residuals conform to a homoscedastic distribution. The $K-S$ test shows that the normality assumption is not met $(p<0.05)$. The regression showed that only the dimension Self-esteem was a significant predictor of voice disturbances, explaining $1.2 \%$ of the variance, being negative (Table 7).

Table 7. Regression Analysis of the Influence of Effective Personality Factors on Voice Disturbance.

\begin{tabular}{|c|c|c|c|c|c|c|c|c|c|}
\hline \multirow{2}{*}{ DV } & \multirow{2}{*}{ IV } & \multirow{2}{*}{ B } & \multirow{2}{*}{$\beta$} & \multicolumn{2}{|c|}{ 95\% Confidence Interval } & \multirow{2}{*}{$R$} & \multirow{2}{*}{$R^{2}$} & \multirow{2}{*}{$\begin{array}{c}R^{2} \\
\text { Corrected }\end{array}$} & \multirow{2}{*}{$\begin{array}{c}\text { Change } \\
\text { at } R^{2}\end{array}$} \\
\hline & & & & Lower Limit & Upper Limit & & & & \\
\hline \multirow{2}{*}{$\begin{array}{c}\text { Voice } \\
\text { Alterations }\end{array}$} & (Constant) & 10.37 & & 8.74 & 12.01 & \multirow{2}{*}{0.11} & \multirow{2}{*}{0.01} & \multirow{2}{*}{0.01} & \multirow{2}{*}{$0.01 *$} \\
\hline & Self-esteem & -0.08 & $-0.11 *$ & -0.14 & -0.03 & & & & \\
\hline
\end{tabular}

Fifthly, the Musculoskeletal Affections factor was regressed. After verifying that there were no significant correlations between this factor and Labor Self-Realisation and Social Self-Realisation, these were excluded from the analysis. The rest of the factors, as a whole, meet the assumptions for the application of linear regression, with the exception of normality, so the results were taken with caution. There are significant correlations between all variables $p<0.05$ indicating an adequate linear association. The Durbin-Watson value $=1.93$, a value between 1.5 and 2.5 , so independence is met. The eigenvalues of VIF are between 0.01 and 1.99 , all less than 10 , which ensures non-multicollinearity. The standardised residuals conform to a homoscedastic distribution. The $K-S$ test shows that the normality assumption is not met $(p<0.05)$. The regression showed that in Musculoskeletal Affections, only the dimension Self-esteem was a significant predictor, explaining 1.3\% of the variance, in a negative direction (Table 8). 
Table 8. Regression Analysis of the Influence of Effective Personality Factors on Musculoskeletal Disorders.

\begin{tabular}{|c|c|c|c|c|c|c|c|c|c|}
\hline \multirow{2}{*}{ DV } & \multirow{2}{*}{ IV } & \multirow{2}{*}{ B } & \multirow{2}{*}{$\beta$} & \multicolumn{2}{|c|}{ 95\% Confidence Interval } & \multirow{2}{*}{$R$} & \multirow{2}{*}{$R^{2}$} & \multirow{2}{*}{$\begin{array}{c}R^{2} \\
\text { Corrected }\end{array}$} & \multirow{2}{*}{$\begin{array}{c}\text { Change } \\
\text { at } R^{2}\end{array}$} \\
\hline & & & & Lower Limit & Upper Limit & & & & \\
\hline \multirow{2}{*}{$\begin{array}{l}\text { Musculoskeletal } \\
\text { Affections }\end{array}$} & (Constant) & 12.32 & & 10.51 & 14.14 & \multirow{2}{*}{0.11} & \multirow{2}{*}{0.01} & \multirow{2}{*}{0.01} & \multirow{2}{*}{$0.01 *$} \\
\hline & Self-esteem & -0.09 & -0.11 * & -0.15 & -0.03 & & & & \\
\hline
\end{tabular}

$* p<0.05$.

Finally, in sixth place, the regression on the Cognitive Affections factor was carried out. After verifying that, on the whole, the assumptions for the application of multiple linear regression were fulfilled, except for normality, the results were taken with caution. There are significant correlations between all variables $p<0.05$ indicating an adequate linear association. The Durbin-Watson value $=2.08$, a value between 1.5 and 2.5 , so independence is met. The eigenvalues of VIF are between 0.01 and 4.96, all less than 10, which ensures non-multicollinearity. The standardised residuals conform to a homoscedastic distribution. The $K-S$ test shows that the normality assumption is not met $(p<0.05)$. The regression showed that in relation, to the Cognitive Affections, the dimensions Self-esteem, Resolute Self-Efficacy, Social Self-Realisation, and Labor Self-Realisation were significant predictors, explaining $11.9 \%$ of the variance, in a negative sense for all of them except for Labor Self-Realisation (Table 9).

Table 9. Regression Analysis of the Influence of Effective Personality Factors on Cognitive Affections.

\begin{tabular}{|c|c|c|c|c|c|c|c|c|c|}
\hline \multirow{2}{*}{ DV } & \multirow{2}{*}{ IV } & \multirow{2}{*}{ B } & \multirow{2}{*}{$\beta$} & \multicolumn{2}{|c|}{ 95\% Confidence Interval } & \multirow{2}{*}{$R$} & \multirow{2}{*}{$R^{2}$} & \multirow{2}{*}{$\begin{array}{c}R^{2} \\
\text { Corrected }\end{array}$} & \multirow{2}{*}{$\begin{array}{c}\text { Change } \\
\text { at } R^{2}\end{array}$} \\
\hline & & & & Lower Limit & Upper Limit & & & & \\
\hline \multirow{5}{*}{$\begin{array}{l}\text { Cognitive } \\
\text { Affections }\end{array}$} & (Constant) & 21.75 & & 19.44 & 24.07 & \multirow{5}{*}{0.34} & \multirow{5}{*}{0.12} & \multirow{5}{*}{0.11} & \multirow{5}{*}{$0.01 *$} \\
\hline & Self-esteem & -0.16 & $-0.19 *$ & -0.24 & -0.07 & & & & \\
\hline & $\begin{array}{c}\text { Resolute } \\
\text { Self-Efficacy }\end{array}$ & -0.23 & -0.19 * & -0.34 & -0.13 & & & & \\
\hline & $\begin{array}{c}\text { Social } \\
\text { Self-Realisation }\end{array}$ & -0.08 & $-0.12 *$ & -0.13 & -0.03 & & & & \\
\hline & $\begin{array}{c}\text { Labor } \\
\text { Self-Realisation }\end{array}$ & 0.11 & $0.12 *$ & 0.02 & 0.19 & & & & \\
\hline
\end{tabular}

* Bonferroni correction ( $p$-value $0.05 / 4$ tests $=0.0125)$.

In order to test the possible relationships between the dimensions of Efficacy Personality and Occupational Health, a Structural Equation model was used. As an initial step in proposing the model, a Confirmatory Factor Analysis was performed to obtain appropriate fit indices. Model 1, relating the four Efficacy Personality factors to the six Occupational Health factors (Figure 1), and Model 2 relating Efficacy Personality to the Occupational Health Satisfaction and Self-Efficacy factors (Figure 2), more related to health gain aspects, were tested. These analyses were performed using the Maximum Likelihood procedure after checking that the multivariate normality assumption indicated a Mardia coefficient of less than 70 (Model 1 r.c. = 12.94; Model 2 and SEM r.c. = 17.93). Authors such as Rodríguez and Ruiz [66] consider that this is the method that provides the best results even if there is a distance from the normality assumption.

When testing both models (Table 10) it was found, on the one hand, that in Model 1, the Efficacy Personality questionnaire showed adequate composite reliability (CR) and average variance extracted (AVE), while Occupational Health showed inadequate CR and AVE. In addition, the fit indices show a poor fit of the data with this model. On the other hand, in Model 2, both the Efficacy Personality and the Occupational Health questionnaires have adequate HR and AVE, and the indices also show a good fit to the model, with the exception of the CMIN/DF index, possibly due to the sample size. 
When analysing the structural equation model (SEM) of the relationship between Efficacy Personality and Occupational Health (Figure 3), it was observed that there is a significant, direct, and positive relationship between both constructs (standardised regression weight $=0.74 ; p<0.001$ ). Furthermore, the $R^{2}$ indicates that the model explains $55.0 \%$ of the variance in Occupational Health in the aspects related to health gain (Satisfaction and Self-efficacy). This indicates the clear protective role of the Efficacy Personality on Occupational Health.

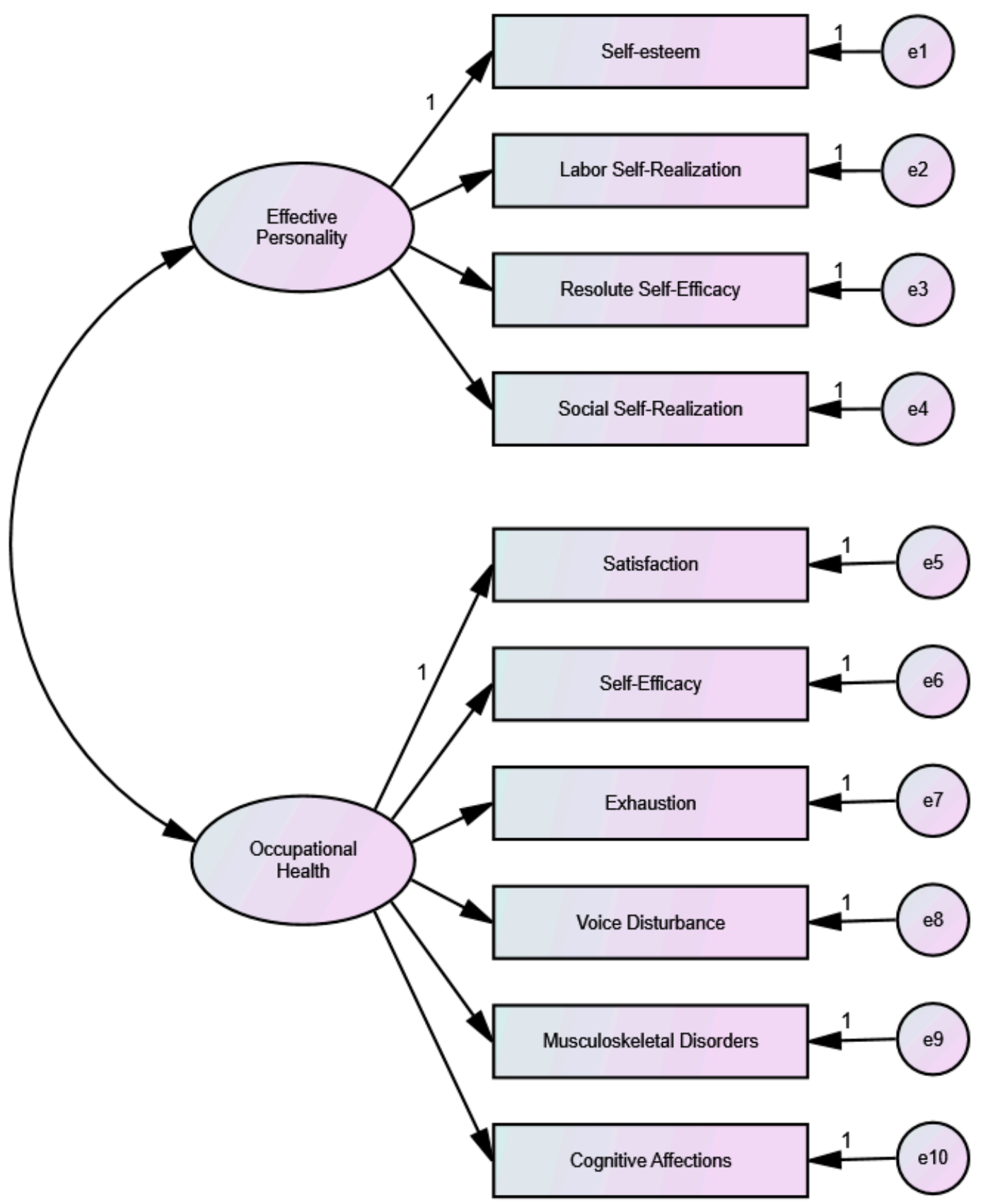

Figure 1. Model 1: Effective Personality Relationship with Occupational Health. 


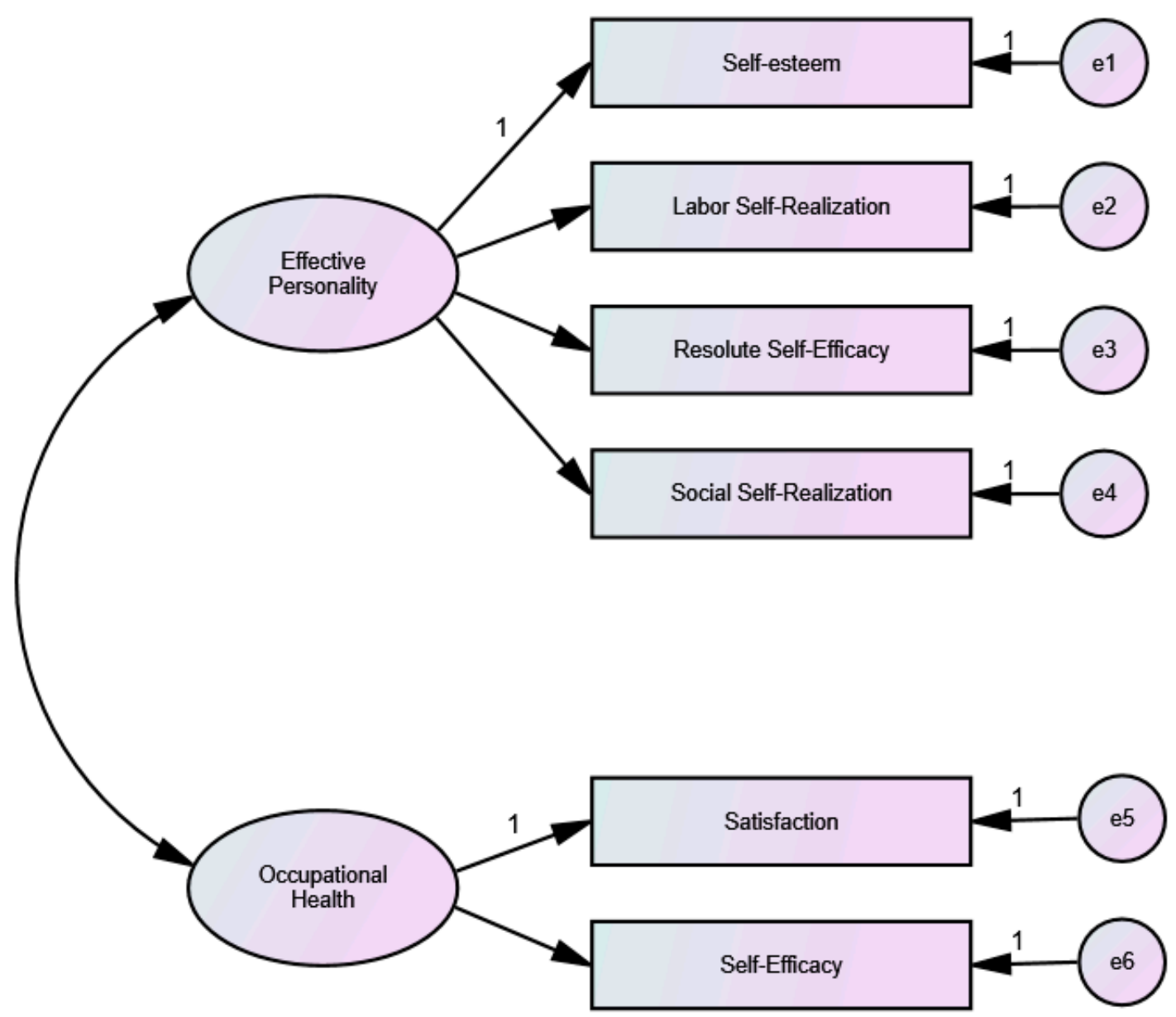

Figure 2. Model 2: Effective Personality Relationship with Satisfaction and Self-efficacy factors.

Table 10. Model fit and validity and reliability indices.

\begin{tabular}{|c|c|c|c|c|}
\hline & \multicolumn{2}{|c|}{ Model 1} & \multicolumn{2}{|c|}{ Model 2} \\
\hline CMIN/DF & \multicolumn{2}{|c|}{19.67} & \multicolumn{2}{|c|}{8.96} \\
\hline GFI & \multicolumn{2}{|c|}{0.80} & \multicolumn{2}{|c|}{0.97} \\
\hline CFI & \multicolumn{2}{|c|}{0.73} & \multicolumn{2}{|c|}{0.96} \\
\hline NFI & \multicolumn{2}{|c|}{0.72} & \multicolumn{2}{|c|}{0.95} \\
\hline SRMR & \multicolumn{2}{|c|}{0.12} & \multicolumn{2}{|c|}{0.04} \\
\hline & $\begin{array}{c}\text { Effective } \\
\text { Personality }\end{array}$ & $\begin{array}{c}\text { Occupational } \\
\text { Health }\end{array}$ & $\begin{array}{c}\text { Effective } \\
\text { Personality }\end{array}$ & $\begin{array}{c}\text { Occupational } \\
\text { Health }\end{array}$ \\
\hline CR & 0.80 & 0.02 & 0.80 & 0.78 \\
\hline AVE & 0.51 & 0.26 & 0.50 & 0.65 \\
\hline MSV & 0.58 & 0.58 & 0.55 & 0.55 \\
\hline $\operatorname{MaxR}(\mathrm{H})$ & 0.82 & 0.78 & 0.83 & 0.86 \\
\hline $\begin{array}{l}\text { Effective } \\
\text { Personality }\end{array}$ & 0.71 & $0.76^{* * *}$ & 0.71 & $0.74^{* * *}$ \\
\hline $\begin{array}{c}\text { Occupational } \\
\text { Health }\end{array}$ & & 0.51 & & 0.81 \\
\hline
\end{tabular}




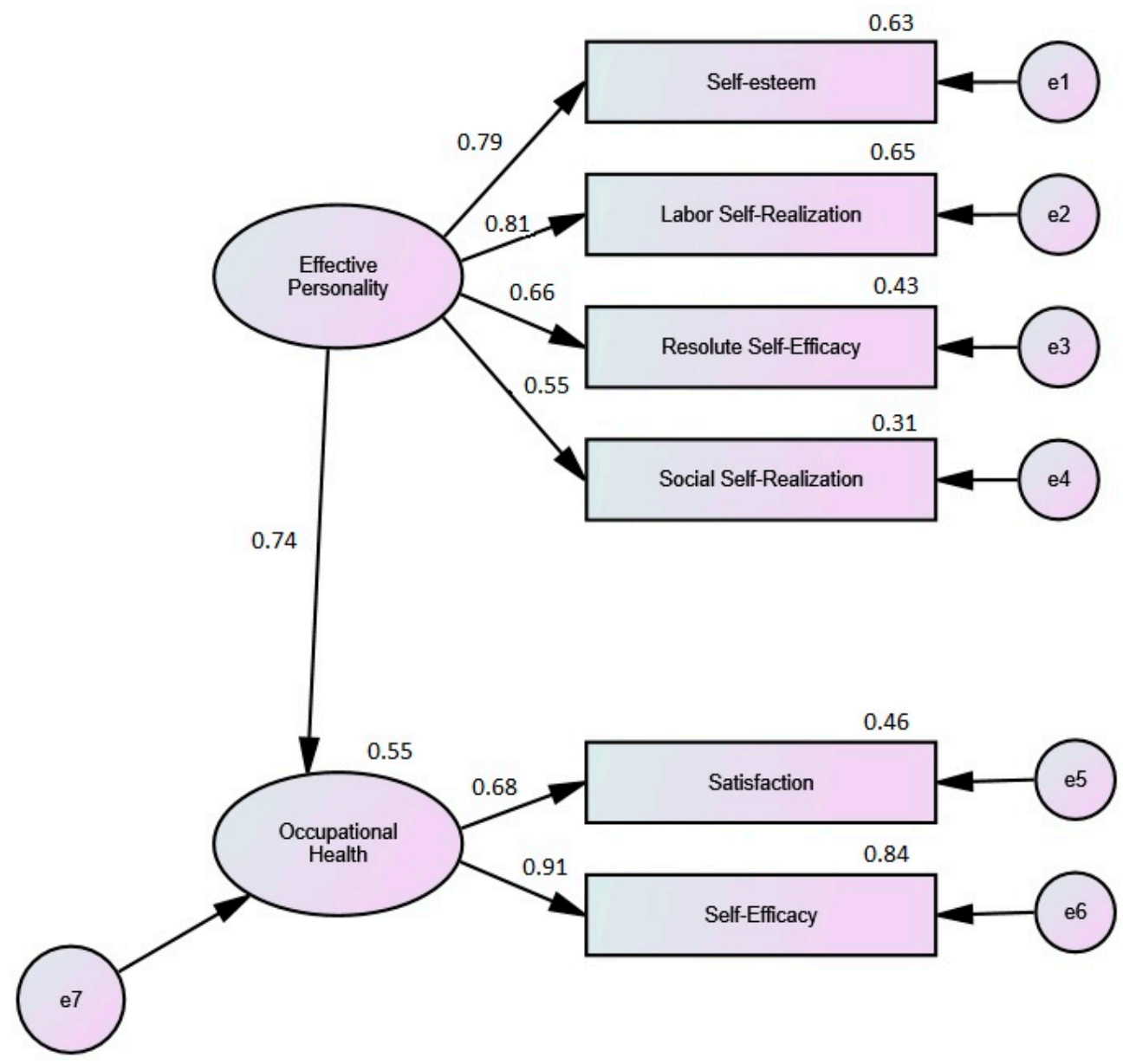

Figure 3. Standardised Regression Weights of the SEM: Model of Structural Equations of Effective Personality Relationship with Satisfaction and Self-efficacy Factors.

\section{Discussion}

This paper aimed to analyse the relationship between Efficacy Personality and Teacher Occupational Health and, more specifically, between the dimensions that make up the first construct and the dimensions of Satisfaction, Self-efficacy, and burnout of the second.

As a starting hypothesis, it was proposed that there is a positive influence between the Efficacy Personality and the manifestations of health gain (Self-efficacy and Satisfaction) and a negative influence with the manifestations of health loss (Exhaustion, Cognitive Affections, Musculoskeletal Affections, and Voice Alterations).

In the light of the results obtained, it can be indicated that this hypothesis is partially confirmed, since there is a clear relationship between the dimensions of Efficacy Personality and the health gain factors, and to a lesser extent with the loss factors (these results are not statistically significant).

More specifically, positive correlations were found between manifestations of health gain and all dimensions of the Efficacy Personality. This indicates that high Self-Efficacy and Satisfaction correspond to high levels of Self-Esteem, Labor Self-Realisation, Resolute Efficacy, and Social Self-Realisation. Therefore, teachers who perceive themselves as having the good professional ability and feel satisfied with their teaching work are people with high self-esteem, with the ability to make adequate internal attributions of professional achievements, have high expectations, are effective in problem-solving, and have adequate social skills that provide them with a consolidated social support network.

This positive relationship is corroborated by linear regression analyses that show the influence of the Efficacy Personality dimensions on Occupational Health. In addition, 
structural equation analysis confirms the influence of Efficacy Personality on the factors of Self-efficacy and Satisfaction.

The above results are in line with Kobasa [53], who found that subjects with high scores on resilient personality factors show higher levels of protection against work stress. This model characterises a resilient personality by three basic components: engagement (the ability to be involved in life activities), control (the person's ability to take control of his or her life), and challenge (the ability to see change as a challenge rather than a threat). It is worth noting that a wider range of dimensions are integrated into the Efficacy Personality construct.

More recent studies also confirm the influence of personal resources on teacher satisfaction and well-being [7,67-73]. Other authors also point to the importance of these resources for teacher performance [74].

We also found agreement with other research [75] that confirms the role of self-esteem in promoting behaviours related to occupational health. This was also observed with those that relate self-efficacy with teacher motivation [76-79], as well as studies that confirm that this relationship is positive, finding that teachers with high levels of self-efficacy are more motivated and more enthusiastic about the teaching process [80].

Other authors also explain the importance of the positive relationships found [81], indicating that commitment to the student, having good instructional strategies, and effective classroom management have a positive impact on teachers' happiness.

As for the manifestations of loss of health, it has been found that it correlates negatively, although low and not significantly, with Effective Personality. The most relevant relationships were found between Cognitive Affections and burnout with the Effective Personality scale.

By deduction of the profiles found in the teachers who presented high values in the dimensions of Efficacy Personality, we can point out the following notes. Specifically, about the factor Cognitive Affections, it has been found that the subjects with the greatest personal resources, those who obtain the highest scores in the dimensions of the Efficacy Personality construct, have the lowest rates of cognitive affect. It should be noted that this dimension is one of the main factors involved in the generation of negative spirals of health loss in the teaching profession (crisis of professional efficacy and development of burnout).

On the other hand, the Exhaustion factor shows that those teachers who present a greater presence of personal resources (Self-concept, Self-esteem, Resolution self-efficacy, and Social Self-Realisation) obtained lower scores in the Exhaustion factor of the teacher occupational health model, giving, therefore, these resources an important moderating and protective role. It should be noted in this respect that the burnout factor is a decisive element in the spirals of health loss in the teacher occupational health model (illness processes and depressive disorders) and that it also corresponds to the central dimension of the burnout syndrome.

This indicates that teachers' perception of a decrease in their cognitive abilities (concentration problems, lack of memory, frequent distractions, and obsessive thinking) is negatively related to their self-esteem, self-efficacy in solving problems, and Social and Labor Self-Realisation, causing a significant feeling of vulnerability and insecurity. In addition, a high state of burnout leads to a low sense of self-esteem, low motivation, a low tendency to make positive causal attributions, and developing low expectations of success.

These results are in line with those found by other authors, who state that people with low levels of Self-esteem feel less effective in factors such as communication, understanding, attention, and excellence [82,83]. In addition, low levels of burnout are found, firstly, in teachers who have a high profile of efficacy, attributions, and positive expectations of success [84]. Secondly, these levels are also found in teachers with high sociability, well-being, and self-control [7]. This shows the importance of the factors of the Efficacy Personality construct since several of them are part of its dimensions (Self-esteem, Attributions, Expectations, and Sociability). 


\section{Conclusions}

The results confirm the relationship between the dimensions of the Efficacy Personality construct and the dimensions that make up the gain in Teacher Occupational Health (SelfEfficacy and Satisfaction). No such clear evidence was found to the dimensions of loss (Exhaustion, Cognitive Affections, Musculoskeletal Affections, and Voice Alterations).

Therefore, we can consider the protective function of the Efficacy Personality on Teachers' Occupational Health.

It is evident that the strengthening of personal competencies and resources is a firstorder necessity for an effective and healthy exercise of the teaching profession. It is essential to promote the development of personal health resources in the teaching profession, both at the level of initial and in-service teacher training.

In this sense, the construct of Effective Personality has developed programmess that allow a continuous education and training of the different dimensions that constitute it and that have already been implemented in different educational and professional contexts [85].

Education and training should be complementary to the analysis of other organisational and group aspects of the work context since together they determine an efficient, effective, and healthy professional performance.

\section{Limitations and Future Directions}

Below, we point out the main limitations that we consider to be present in this study and that should be taken into account when interpreting and generalising the results.

The first limitation refers to the type of cross-sectional design employed. It would be interesting to develop a longitudinal design that would allow us to study the evolution of the variables analysed, and thus be able to establish causal relationships.

Secondly, another limitation is the lower value of the reliability coefficients of the "Resolute self-efficacy" factor, possibly due to the smaller number of items that make up this dimension. Despite this, it is within acceptable values for the statistical treatment of the data. As a line for the future, it would be advisable to increase the number of items and reliability of this factor.

Concerning the sample, it would be desirable to have a larger number of participants as well as to extend it to the different regions of the country.

Another limitation is the fact that the assumption of normality in the multiple linear regression test was not met, which means that the results should be interpreted with caution. However, the other assumptions were met.

On the other hand, no clear influence has been found for health loss factors, so it would be necessary to look into this aspect in greater depth.

Given the importance of the results, it would be advisable for future studies to extend the sample to other cultural contexts and other levels of teaching staff, such as university teachers, and other variables such as gender and age.

It would also be interesting to know to what extent these dimensions are present in each of the multivariate typologies of the Efficacy Personality construct. This study will allow us to deepen our knowledge of needs and opportunities for improvement with resources that must necessarily form part of teaching competencies.

In the future, it would also be interesting to apply effective personality development programs that train the different dimensions and to monitor their effectiveness with this population [85].

Author Contributions: Conceptualisation, M.E.M.-P., A.F.A.-D., C.D.-G. and R.d.1.F.-A.; investigation, M.E.M.-P., A.F.A.-D., R.d.1.F.-A. and M.S.G.-R.; formal analysis, M.E.M.-P. and C.D.-G.; data curation, C.D.-G.; writing — original draft preparation, M.E.M.-P., A.F.A.-D., R.d.1.F.-A., M.S.G.-R. and F.J.S.-S.; writing—review and editing, M.E.M.-P., A.F.A.-D., C.D.-G., M.S.G.-R. and C.G.G.-R.; visualisation, C.G.G.-R., A.F.A.-D. and F.J.S.-S.; project administration, M.E.M.-P. and R.d.1.F.-A. All authors have read and agreed to the published version of the manuscript.

Funding: This study was not financially supported. 
Institutional Review Board Statement: The study was conducted according to the guidelines of the Declaration of Helsinki and approved by The Code of Good Research Practices at Universidad Complutense de Madrid (05 BOUC20).

Informed Consent Statement: The authors affirm that all procedures contributing to this work comply with the ethical standards of the relevant national and institutional committees on human experimentation following the Code of Good Research Practice of the Complutense University of Madrid (05 BOUC 20). All participants provided written informed consent following the Declaration of Helsinki. The participants were informed and assured of anonymity and confidentiality. Based on the data collected, analysed statistically and presented, it is impossible to identify the survey participants.

Data Availability Statement: The datasets used and/or analysed during the current study are available from the corresponding author.

Acknowledgments: We would like to thank all the older adults who participated in this research study.

Conflicts of Interest: The authors declare that the research was conducted in the absence of any commercial or financial relationships that could be construed as a potential conflict of interest.

\section{References}

1. OMS Entornos Laborales Saludables: Fundamentos y Modelo de la OMS: Contextualización, Prácticas y Literatura de Apoyo; World Health Organization: Geneva, Switzerland, 2010.

2. Aldrup, K.; Carstensen, B.; Köller, M.M.; Klusmann, U. Measuring Teachers' Social-Emotional Competence: Development and Validation of a Situational Judgment Test. Front. Psychol. 2020, 11, 8-92. [CrossRef]

3. Pacheco, N.E.; López, S.M.; Gómez, M.S. La importancia de la inteligencia emocional del profesorado en la misión educativa: Impacto en el aula y recomendaciones de buenas prácticas para su entrenamiento. Voces De La Educ. 2019, Extra 2, 74-97.

4. Peláez-Fernández, M.; Mérida-López, S.; Sanchez-Alvarez, N.; Extremera, N. Managing Teachers' Job Attitudes: The Potential Benefits of Being a Happy and Emotional Intelligent Teacher. Front. Psychol. 2021, 12, 661151. [CrossRef]

5. Romano, L.; Tang, X.; Hietajärvi, L.; Salmela-Aro, K.; Fiorilli, C. Students' Trait Emotional Intelligence and Perceived Teacher Emotional Support in Preventing Burnout: The Moderating Role of Academic Anxiety. Int. J. Environ. Res. Public Health 2020, 17, 4771. [CrossRef]

6. Solomon, C.; Lambie, G. Hispanic teachers' experiences with occupational stressors while working in Title I elementary schools. J. Lat. Educ. 2020, 19, 148-163. [CrossRef]

7. Fiorilli, C.; Benevene, P.; De Stasio, S.; Buonomo, I.; Romano, L.; Pepe, A.; Addimando, L. Teachers'Burnout: The Role of Trait Emotional Intelligence and Social Support. Front. Psychol. 2019, 10, 27-43. [CrossRef]

8. Gutiérrez-Santander, P.; Morán-Suárez, S.; Sanz-Vázquez, I. Estrés docente: Elaboración de la escala ED-6 para su evaluación. Relieve 2005, 11, 47-61. Available online: http://www.uv.es/relieve/v11n1/relievev11n1_3.htm (accessed on 16 May 2021). [CrossRef]

9. Szczygiel, D.; Mikolajczak, M. Emotional Intelligence Buffers the Effects of Negative Emotions on Job Burnout in Nursing. Front. Psychol. 2018, 9, 1-10. [CrossRef]

10. Lazarus, R.S. Estrés y Emoción. Manejo e Implicaciones en Nuestra Salud; DDB: Bilbao, Spain, 2000.

11. Larson, M.; Luthans, F. Potential added value of psychological capital in predicting work attitudes. J. Leadersh. Organ. Stud. 2006, 13, 307-324. [CrossRef]

12. Llorens, S.; Martinez, I.; Salanova, M. Organizaciones saludables y resilientes. In Psicología Positiva nas Organizacoes e no Trabalho, 1st ed.; Psicología Organizacional; Veltor Editora: São Paulo, Brasil, 2017; pp. 63-76.

13. Luthans, F.; Avolio, B.J.; Avey, J.B.; Norman, S.M. Psychological capital: Measurement and relationship with performance and satisfaction. Pers. Psychol. 2007, 60, 541-572. [CrossRef]

14. Moreno-Jiménez, B.; Garrosa, E.; Corso, S.; Boada, M.; Rodríguez-Carvajal, R. Personalidad resistente y capital psicológico: Las variables personales positivas y los procesos de agotamiento y vigor. Psicothema 2012, 24, 79-86.

15. Schaufeli, W.B.; Salanova, M. Enhancing work engagement through the management of human resources. In The Individual in the Changing Working Life; Naswall, K., Sverke, M., Hellgren, Y.J., Eds.; Cambrigde University Press: Cambrigde, UK, 2008; pp. 380-404.

16. LPRL. Ley 31/1995, de 8 de noviembre, de prevención de Riesgos Laborales. Boletín Oficial del Estado 1995, 269, 32590-32611.

17. Fernández-Puig, V.; Longás, J.; Chamarro, A.; Virgili, C. Evaluando la salud laboral de los docentes de centros concertados: El Cuestionario de Salud Docente. J. Work Organ. Psychol. 2015, 31, 175-185. [CrossRef]

18. Gil-Monte, P.; Peiró, J.M. Perspectivas teóricas y modelos interpretativos para el estudio del síndrome de quemarse por el trabajo An. De Psicol. 1999, 15, 261-268.

19. Halbesleben, J.R.; Demerouti, E. The construct validity of an alternative measure of burnout: Investigating the English translation of the Oldenburg Burnout Inventory. Work Stress 2005, 19, 208-220. [CrossRef] 
20. Steinhardt, M.A.; Smith, S.E.; Faulk, K.E.; Gloria, C.T. Chronic Work Stress and Depressive Symptoms: Assessing the Mediating Role of Teacher Burnout. Stress Health 2011, 27, 420-429. [CrossRef]

21. Calvete, E.; Villa, A. Burnout y síntomas psicológicos: Modelo de medidas y relaciones estructurales. Ansiedad Y Estrés 2000, 6 , 117-130. Available online: https:/ / dialnet.unirioja.es/revista/97/V/6 (accessed on 29 August 2021).

22. Freudenberger, H.J. Burnout: The high cost of high achievement. Child. Youth Serv. Rev. 1983, 5, 307-309. [CrossRef]

23. Gil-Monte, P. El Síndrome de Quemarse por el Trabajo (Burnout): Una Enfermedad Laboral en la Sociedad del Bienestar; Pirámide: Madrid, Spain, 2005.

24. Golembiewski, R.T.; Munzenrider, R.F.; Stevenson, J. Stress in Organizations; Praeger: New York, NY, USA, 1986.

25. Maslach, C.; Jackson, S.E. The measurement of experienced burnout. J. Occup. Behav. 1981, 2, 99-113. [CrossRef]

26. Pines, A.; Aronson, E. Career Burnout: Causes and Cures; The Free Press: New York, NY, USA, 1988.

27. Maslach, C.; Schaufeli, W.B.; Leiter, M.P. Job Burnout. Annu. Rev. Psychol. 2001, 52, 397-422. [CrossRef]

28. Demerouti, E.; Bakker, A.; Nachreiner, F.; Schaufeli, W.B. The Job Demands-Resources Model of Burnout. J. Appl. Psychol. 2001, 86, 499-512. [CrossRef]

29. Hakanen, J.; Bakker, A.B.; Schaufeli, W.B. Burnout and work engagement among teachers. J. Sch. Psychol. 2006, 43, 495-513. [CrossRef]

30. Salanova, M.; Schaufeli, W.B. A cross-national study of work engagement as a mediator between job resources and proactive behaviour. Int. J. Hum. Resour. Manag. 2008, 19, 116-131. [CrossRef]

31. Fernet, C.; Guay, F.; Senécal, C.; Austin, S. Predicting intraindividual changes in teacher burnout: The role of perceived school environment and motivational factors. Teach. Teach. Educ. 2012, 28, 514-525. [CrossRef]

32. Lorente, L.; Salanova, M.; Martínez, I.; Schaufeli, W.B. Extensive of the Job Demands-Resources model in the prediction of burnout and engagement among teachers over time. Psicothema 2008, 20, 354-360.

33. ETUCE. Teacher's Work-Related Stress: Assessing, Comparing and Evaluating the Impact of Psychosocial Hazards on Teachers at Their Workplace; European Trade Union Committee for Education: Brussels, Belgium, 2011. Available online: http:/ / etuce.homestead. com/Publications2011/ (accessed on 21 June 2021).

34. Vermeeren, B.; Kuipers, B.; Steijn, B. Two faces of the satisfaction mirror: A study of work environment, job satisfaction, and customer satisfaction in Dutch municipalities. Rev. Public Pers. Adm. 2012, 31, 171-189. [CrossRef]

35. Fredrickson, B.L.; Joiner, T. Positive emotions trigger upward spirals toward emotional well-being. Am. Psychol. Soc. 2002, 13, 172-175. [CrossRef]

36. Simbula, S.; Guglielmi, D. I am engaged, I feel good, and I go the extra-mile: Reciprocal relationships between work engagement and consequences. J. Work Organ. Psychol. 2013, 29, 117-125. [CrossRef]

37. Escalona, E.; Sánchez, L.; González, M. Estrategias participativas en la identificación de la carga de trabajo y problemas de salud de docentes de escuelas primarias. Salud Los Trab. 2007, 15, 17-35. Available online: https://dialnet.unirioja.es/descarga/ articulo/2391319.pdf (accessed on 26 July 2021).

38. McAleavy, G.J.; Adamson, G.; Hazlett, D.E.; Donegan, H.A.; Livesey, G.E. Modelling determinants of the vocal health of teachers in Northen Ireland: Implications for educational policy and practice. J. Public Health 2009, 122, 691-699. [CrossRef]

39. Ranchal, A.; Vaquero, M. Burnout, variables fisiológicas y antropométricas: Un estudio. Revista de Medicina y Seguridad en el Trabajo 2008, 54, 47-55. [CrossRef]

40. Ademys. Salud y Condiciones de Trabajo en el Sector Docente: Diagnóstico y Respuestas Posibles; Ademys Asociación Docente: Buenos Aires, Argentina, 2011.

41. Gay, E.I.; Milán, M.M.; Noguera, M.; Embuena, E. Condicions de seguretat i salut del treballdocent; Rosa Sensat: Barcelona, Spain, 2003.

42. Solana, M. Riscos musculoesquelètics i higiene postural en la docència. In Cap a la Prevenció de Riscos a L'escola; Longás, J., Ed.; Cossetània: Valls, Spain, 2011.

43. Moya-Albiol, L.; Serrano, M.A.; González-Bono, E.; Rodríguez-Alarcón, G.; Salvador, A. Respuesta psicofisiológica de estrés en una jornada laboral. Psicothema 2005, 17, 205-211.

44. Moyano, N.; Riaño-Hernández, D. Burnout escolar en adolescentes españoles: Adaptación y validación del School Burnout Inventory. Ansiedad Y Estrés 2013, 19, 95-113.

45. Sandi, C.; Venero, C.; Cordero, M.I. Estrés, Memoria y Trastornos Asociados; Ariel Neurociencia: Barcelona, Spain, 2001.

46. Sandström, A.; Rhodin, I.N.; Lundberg, M.; Olsson, T.; Nyberg, L. Impaired cognitive performance in patients with chronic burnout syndrome. Biol. Psychol. 2005, 69, 271-279. [CrossRef]

47. Salanova, M.; Llorens, S.; Schaufeli, W.B. Yes, I can, I feel good, and I just do it! On gain cycles and spirals of efficacy beliefs, affect, and engagement. Applied Psychology. Int. Rev. 2011, 60, 255-285. [CrossRef]

48. Flores, M.D.; Fernández-Castro, J. Creencias de los profesores y estrés docente en función de la experiencia profesional. Estud. De Psicol. 2004, 25, 343-357. [CrossRef]

49. Schaufeli, W.B.; Salanova, M. La evaluación de riesgos psicosociales en el trabajo. Rev. De Prevención Trab. Y Salud 2002, 20, 4-9. [CrossRef]

50. Xanthopoulou, D.; Bakker, A.; Fishbach, A. Work engagement among employees facing emotional demands. J. Pers. Psychol. 2013, 12, 74-84. [CrossRef] 
51. Skaalvik, E.M.; Skaalvik, S. Teacher self-efficacy and teacher burnout: A study of relations. Teach. Teach. Educ. 2010, 26, 1059-1069. [CrossRef]

52. Kobasa, S.C. Stressful life events, personality and health: An inquiry into hardiness. J. Personal. Soc. Psychol. 1979, 37, 1-11. [CrossRef]

53. Kobasa, S.C. The hardy personality: Toward a social psychology of stress and health. In Social Psychology of Health and Illness; Sanders, G.S., Suls, J., Eds.; Lawrence Erlbaum Associates, Inc.: Hillsdale, NJ, USA, 1982.

54. Antonovsky, A. Health, Stress, and Coping; Jossey-Bass Social and Behavioral Science: San Francisco, CA, USA, 1982.

55. Martín del Buey, F.; Martín-Palacio, M.E.; Di Giusto, C. La Personalidad Eficaz, Eficiente Y Efectiva (Emprendedora, Resistente, Madura); Editorial Académica Española: Beau Bassin, Mauritius, 2019.

56. Garrosa, E.; Carmona, I. Salud laboral y bienestar. Incorporación de modelos positivos a la comprensión y prevención de los riesgos psicosociales del trabajo. Med. Y Segur. Del Trab. 2011, 57, 224-238. [CrossRef]

57. Navarro, A.; Bueno, B. Afrontamiento de problemas de salud en personas muy mayores. An. Psicol. 2015, 31, 1008-1017. [CrossRef]

58. Hernández Sampieri, R. Metodología de Investigación, 5th ed.; McGraw Hill: Mexico City, Mexico, 2005.

59. Castellanos, S.; Martín, M.E.; Dapelo, B. Cuestionario de Personalidad Eficaz en Población Adulta de 30 a 60 años. Rev. Orientación Educ. 2012, 26, 15-30.

60. Kline, R.B. Principles and Practices of Structural Equation Modeling; The Guilford Press: New York, NY, USA, 1998.

61. Jöreskog, K.G.; Sörbom, D. LISREL VI: Analysis of Linear Structural Relationships by Maximum Likelihood and Least Square Methods; Scientific Software: Mooresville, IN, USA, 1986.

62. Tanaka, J.S. Multifaceted conceptions of fit in structural equation models. In Testing Structural Equation Models; Bollen, K.A., Longm, J.S., Eds.; Sage: Newbury Park, CA, USA, 1993; pp. 10-39.

63. Bentler, P.M.; Bonnet, D.G. Significance tests and goodness-of-fit in the analysis of covariance structures. Psychol. Bull. 1980, 88, 588-606. [CrossRef]

64. Browne, M.W.; Cudeck, R. Alternative ways of assessing model fit. In Testing Structural Equation Models; Bollen, K.A., Long, J.S., Eds.; Sage: Newbury Park, CA, USA, 1993; pp. 136-162.

65. Pérez, C. Multivariate Data Analysis Techniques; Pearson Prentice Hall: Madrid, Spain, 2004.

66. Rodríguez, M.N.; Ruiz, M.A. Attenuation of the asymmetry and kurtosis of the observed scores by means of variable transformations: Impact on the factorial structure. Psicológica 2008, 29, 205-227.

67. Aghababaei, N.; Arji, A. Well-being and the HEXACO model of personality. Personal. Individ. Differ. 2014, 56, 139-142. [CrossRef]

68. Adina, A.; Clipa, O. Teacher's satisfaction with life, job satisfaction and their emotional intelligence. Procedia Soc. Behav. Sci. 2012, 33, 498-502. [CrossRef]

69. Day, C.; Gu, Q. Educadores resilientes, escuelas resilientes. RECIE 2015, 1, 122-123. [CrossRef]

70. Hargreaves, A.; Fullan, M. Capital Profesional. Transformar la Enseñanza en Cada Escuela; Morata: Madrid, Spain, 2014.

71. Rodríguez-Carvajal, R.; Díaz, D.; Moreno-Jiménez, B.; Blanco, A.B.; Van-Dierendonck, D. Vitalidad y Recursos Internos como Componentes del Constructo de Bienestar Psicológico. Psicothema 2010, 22, 36-70.

72. Di Fabio, A.; Kenny, M.E. Promoting Well-Being: The Contribution of Emotional Intelligence. Front. Psychol. 2016, 7, 1-13. [CrossRef]

73. Di Fabio, A. The Psychology of Sustainability and Sustainable Development for Well-Being in Organizations. Front. Psychol. 2017, 8, 1-7. [CrossRef]

74. Sánchez, F.; Martín, M.E.; De la Fuente, R. La escuela como entorno laboral saludable. Importancia del desarrollo de recursos personales en el trabajo docente. Rev. Orientación Educ. 2019, 33, 82-97.

75. Benevene, P.; De Stasio, S.; Fiorilli, C.; Buonomo, I.; Ragni, B.; Briegas, J.M.; Barni, D. Effect of Teachers' Happiness on Teachers' Health. The Mediating Role of Happiness at Work. Front. Psychol. 2019, 10, 2449. [CrossRef]

76. Caprara, G.; Barbaranelli, C.; Borgogni, L.; Petitta, L.; Rubinacci, A. Teachers', school staff's and parents' efficacy beliefs as determinants of attitudes toward school. Eur. J. Psychol. Educ. 2003, 18, 15-31. Available online: https://link.springer.com/ article/10.1007/BF03173601 (accessed on 20 July 2021). [CrossRef]

77. Caprara, G.; Barbaranelli, C.; Borgogni, L.; Steca, P. Efficacy Beliefs as Determinants of Teachers' Job Satisfaction. J. Educ. Psychol. 2003, 95, 821-832. [CrossRef]

78. Bamburg, J. Raising Expectations to Improve Student Learning; NCREL: Waschington, DC, USA, 1994 ; Volume 1.

79. Rodríguez, S.; Núñez, J.; Valle, A.; Blas, R.; Rosario, P. Auto-eficacia Docente, Motivación del Profesor y Estrategias de Enseñanza. Escr. Psicol. 2009, 3, 1-7. Available online: http://www.escritosdepsicologia.es/descargas/revistas/vol3_1/escritospsicologia_v3 _1_1srodriguez.pdf (accessed on 15 June 2021). [CrossRef]

80. Tschannen-Moran, M.; Woolfolk, A. Teacher efficacy: Capturing an elusive construct. Teach. Teach. Educ. 2001, 17, 783-805. [CrossRef]

81. Perandones, T.; Herrera, L.; Lledó, A. Felicidad subjetiva y autoeficacia docente en profesorado de República Dominicana y España. Eur. J. Investig. Health Psychol. Educ. 2013, 3, 277-288. [CrossRef]

82. Blanco, H.; Aguirre, J.; Barrón, J.; Blanco, J. Composición Factorial de la Escala de Autoeficacia Académica en Universitarios Mexicanos. Form. Univ. 2016, 9, 81-88. [CrossRef] 
83. Gutierrez-García, A.; Landeros-Velázquez, M. Evaluación de Funciones Ejecutivas en Estudiantes Universitarios con Niveles de Autoeficacia Percibida Baja. Rev. Elec. Psic. Izt. 2017, 20, 397-426.

84. Ferradás, M.; Freire, C.; García-Bértoa, A.; Núñez, J.; Rodríguez, S. Teacher profiles of psychological capital and their relationship with Burnout. Sustainability 2019, 11, 5096. [CrossRef]

85. Martín del Buey, F.; Granados, P.; Martín Palacio, M.E. Program for effective personality development in educational/professional settings. In Educational Psychology and Teacher Training: New Challenges, New Answers; Vicente Castro, F., Fajardo Caldera, M.I., Eds.; Psicoex: Teruel, Spain, 2002; pp. 339-347. 